\title{
Improvement of the grapevine variety 'Kadarka' by the selection of new clones
}

\author{
Werner, J. \& Kozma, P. \\ University of Pécs, Research Institute for Viticulture \& Enology \\ H-7634 Pécs, Pázmány P. u. 4., Hungary (e-mail: werner.janos@ @te.hu)
}

\begin{abstract}
Summary: Red wine culture in Hungary was developed due to the grapevine variety 'Kadarka', originated from the Balkans, from the $16^{\text {th }}$ and $17^{\text {th }}$ centuries. 'Kadarka' was the first grapevine variety cultivated on the largest area in Hungary until the 1950's, but its production area has been reduced significantly in the past decades. In the period of Hungarian grapevine reconstruction (from the 1960's), the selection of the grapevine varieties and clones was determined by the system of cultivation (large growing space, large load and mechanized technology) that was based on the aspects of quantity. It did not promote the majority of the autochton and regional grapevine varieties to remain competitive. 'Kadarka' is a grapevine variety having an extraordinary variability in forms; however, a considerable part of its old stocks has disappeared. Nowadays, only two of its high yield clones are cultivated. 'Kadarka' becomes more differentiated from other, red wine producing, grapevine varieties, more preferred and newly requested by the fine aroma, spice, unique harmony of its wine less rich in tannin. The new market and environmental challenges in the field of wine production necessitate the preservation and improvement of the biological basis. In 2001 the Institute of Viticulture and Enology Pécs analyzed an old stock having a variability in forms in order to preserve the development and variability of the biological basis of 'Kadarka'. Clones of great biological value were selected from it, with which the quality and yield security of 'Kadarka' can be increased. In 2010 and in 2012, six clones were submitted for state approval.
\end{abstract}

Keywords: 'Kadarka', clonal selection, maintenance of varieties

\section{Introduction and survey of the literature}

\section{Origin and classification of 'Kadarka'}

'Kadarka' (synonyms: 'Branicevka', 'Csetereska' Serbia, 'Gamza' - Bulgaria, 'Kadarka noir' - France, Negru moale - Romania) came to Hungary from the Balkans, in the period of the Turkish occupation of Hungary, in the 1617 $7^{\text {th }}$ century (Kozma, 1963; Németh, 1967/a; Rácz, 1997; Andrásfalvy, 1999; Cindric et al., 2000). According to Rapaics (1940) and Kozma (1963), it is originated from Asia Minor. Németh (1967/a) and Rácz (1997) consider it having Albanian (around the lake Shkodra) origin. Many varieties of the grapevine variety 'Kadarka', cultivated in ecological conditions far from its place of origin, have been developed that show a significant difference in fertility and in morphological characteristic (Kozma, 1963). Drucker (1906) differentiates three varieties ('Bolond kadarka', 'Rúgós kadarka', 'Nemes kadarka') among 'Kadarka'. Nedelcsev (1938) mentions a green variety, which berry does not get dark even at the stage of full ripening. Kozma (1963) defines five different leaves and their intermediate types (A-'Lúdtalpú', B-'Kordoványos', C-'Nemes', D-'Kereszteslevelü', F-'Fügelevelü') as well. As for Németh (1967/a), 'Kadarka' belongs to the convarietas (proles-Negrul, 1946) pontica subconvararietas balcanica provararietas mesocarpa subprovarietas dalmatica taxonomic group, it creates a variety group (similarly to 'Pinot', for example) and its two varieties are 'Kadarka blue' and 'Kadarka gray'. He emphasizes that only the 'Kadarka blue' variety has a production value (similarly to 'Merlot noir', for example) in which he distinguishes nine subvarieties. The microsatellite marker analysis, made by Halász (2010), confirms the classification of Németh (1967/a) according to which, 'Kadarka'a belongs to the group of pontica convarietas.

\section{Incidence and importance of 'Kadarka'}

In the beginning of the $19^{\text {th }}$ century, two third of the cultivation area of blue grapevine varieties in Hungary was covered by 'Kadarka'. The northern border of its cultivation area is in Hungary (Kozma, 1963).

Its largest cultivation area can be found in the (sandy) soil of the Alföld, and in the wine regions of Szekszárd, Eger and Villány.

In 1960 the cultivation area of 'Kadarka' in Hungary reached 47268 ha that was $23,4 \%$ of the total grapevine cultivation area (Csepregi, 1997). In 2008 it has a territory of 666 ha, in 2010 it was 520 ha, and its portion from the total grapevine cultivation area was under $1 \%$ (Robinson et al., 2012; HNT, 2011). Its significant reduction was the result of the grapevine reconstruction (wide-spaced tall trunk training, large load) starting in the 1960's, which was 
based on the aspect of quantity, and it did not promote the competitiveness of 'Kadarka' having susceptibility to load and vintage (jr. Kozma et al., 2010). In the first decade of new millennium (2001-2011) in Hungary, the grapevine variety 'Kadarka' was supplanted from the $5^{\text {th }}$ to the $8^{\text {th }}$ place in the regional hierarchy of red wine producing grapevine varieties (HNT, 2012). This particular grapevine variety is cultivated in a larger cultivation area, besides Hungary, in Balkan states (Bulgaria - 3169 ha, Albania, Macedonia, Serbia) and in Romania (47 ha), in the wine region of Ménes, which gained its reputation due to the aszu wine made from this grapevine variety (Andrásfalvy, 1999; Csávossy, 2002; Dejeu, 2012; Robinson et al., 2012).

'Kadarka' is a grapevine variety being fertile, resistant to drought, having frost sensitivity and susceptibility to rot and shrivelling. The sugar degree of the must and the colour depth of 'Kadarka' vary in compliance with its vintage. White, rosé, siller, red and aszu wine can be produced from its yield, but it can be utilized as a table grape. Its wine is characteristic, mildly aromatic, elegant with a fresh acid content (Kozma, 1963; Németh, 1967/a; Hajdu, 2010, 2012; Rohály et al., 2012), representing an internal part in one of the most famous wine brand of Hungary, Bikavér (Eperjesi et al., 1998).

\section{Clonal selection of 'Kadarka'}

Although the ancient grapevine varieties (for example 'Pinot noir') are rather heterogeneous, the genetic analogy of their propagated clones stands between 95-99\% (Bessis, 2007; Wegscheider et al., 2009). The maintenance of the divergent varieties and valuable mutations of the grapevine varieties may be assured by the selection and preservation of clones (Boursiquot et al., 1999). Németh (1958, 1970) and Schmid et al., (2009) explain the importance of clonal selection by the detection of the variability of the varieties, the enhancement of the production values of the varieties and by the production of a virus-free propagating material.

In Hungary, the preservation and improvement of biological basis of autochton and some regional varieties have failed to realize.

In Hungary the clonal selection of the grapevine variety 'Kadarka' started in the end of the 1940's (Kozma, 1963; Hajdu, 2010). During this, Kozma ((1954, 1957, 1958/a, b; 1963) and Németh $(1958,1967 / \mathrm{a}$, b) was dealing with the study of the morphological and fertility issues of this particular grapevine variety as well. The cultivation of 'Kadarka' in Hungary is still based on those two, high yield clones (Kt. 4 - Nemes, P. 9 - Füszeres), resulted from the above mentioned study, that were selected in compliance with quantitative aspects (Hajdu, 2010; jr. Kozma et al., 2010). Several new clones of great biological value are needed for the enhancement of the quality and yield security of the variety. The exploration of old plantations possessing variability in forms and the examination of their varieties may assist the selection of these clones (jr. Kozma et al., 2010).

\section{Material and methods}

Clonal selection was completed following a version of a 4-phase method, (Németh, 1958) which was modified to a 3-phase one by Luntz (1990). The aim of the selection was to find and propagate clones with less susceptibility to rotting, with loose cluster, having small or medium berries with thick skin, being deep coloured and taking colour uniformly, having the ability of better sugar accumulation and showing an aromatic flavour.

\section{First step of the selection}

The variability of a 'Kadarka' plantation, which was planted in Parászta field in Szekszárd in 1898, was studied. For the selection, 56 elite stocks were chosen from the stock, which were analysed between 2001 and 2006 (Table 1.). The bud load of the vine-stocks was determined by keeping 4-6 pieces of two-budded short spur (bush training method). The characteristics of the measure of value of the clusters were specified in compliance with the system of OIV (2009) and by the method of values. The quantity of the yield per vine-stock $(\mathrm{kg})$, the average bunch weight (yield quantity/cluster number $-\mathrm{g})$, the sugar content of the must ( $\left.{ }^{0} \mathrm{KMW}\right)$, the acidity of the must $(\mathrm{g} / \mathrm{l})$, the $\mathrm{pH}$ were determined by measurement. The measured data was analyzed by coherence analysis.

\section{Second step of the selection}

The 16 elite stocks, selected during the first step of the selection, was propagated (70-120 vine-stocks per clone) in the Batti field in Szekszárd, and they were evaluated from 2009 to 2011. Vine-stocks were loaded by buds of 4 x 2 (Royat-cordon). The results were compared with the P. 9 clone (Table 1.). The characteristics of the measure of value of the clusters were specified in compliance with the system of OIV (2009) and by the method of values. The productivity coefficients was based on the method of Csepregi (1982) per repetition. The yield quantity $\left(\mathrm{kg} / \mathrm{m}^{2}\right)$, the average bunch weight (yield quantity/cluster number $-\mathrm{g}$ ), the average weight of berries (from 5 clusters and from 100 berries per cluster), the sugar content of the must $\left({ }^{0} \mathrm{KMW}\right)$, the acidity of the must $(\mathrm{g} / \mathrm{l})$, the $\mathrm{pH}$ and the level of rotting (\%) were given in 6 repetitions per clones. A mixed-modell Anova in $\mathrm{R}$ version 2.15.1. ( $R$ Development Core Team, 2011) was used to test the effects of clones, cluster thinning and years on the measured parameters of grapes. Year was considered to be a random factor and clones and cluster thinning were treated as fixed factors. Wine was produced from each clone and in each test, which was evaluated by both analytical and organoleptic methods.

\section{Third step of the selection}

Further viticultural and enological value measurement of the clones, examined particularly during the second step of the selection, will be carried on in the future, in 
Table 1. Plant material of the selection

\begin{tabular}{|l|l|}
\hline I. step of selection & II. step of selection \\
\hline $\begin{array}{l}\text { Szekszárd, Parászta field } \\
\text { 56 elite stock }\end{array}$ & $\begin{array}{l}\text { Szekszárd, Batti field } \\
\text { (P. 101-P. 133) }\end{array}$ \\
$\begin{array}{l}\text { (P. 141-P. 156) } \\
\text { (P. 161-P. 167) }\end{array}$ & P. 165, P. 166, P. 167) \\
\hline
\end{tabular}

Table 2. Comparison of the data of the 16 best performing 'Kadarka' elite stocks with the average values of the 56 'Kadarka' elite stocks (Szekszárd - Parászta field, 2001-2009)

Mean of harvest date: 30 September

\begin{tabular}{|c|c|c|c|c|c|c|c|c|c|c|}
\hline $\begin{array}{c}\text { Number of eltie } \\
\text { stock }\end{array}$ & $\begin{array}{c}\text { Yield } \\
\text { (kg/stock) }\end{array}$ & Variance & $\begin{array}{l}\text { Average } \\
\text { weight of } \\
\text { clusters } \\
\text { (g) }\end{array}$ & Variance & $\begin{array}{c}\text { Sugar } \\
\text { degree } \\
\left({ }^{0} \mathrm{KMW}\right)\end{array}$ & Variance & $\begin{array}{c}\text { Total } \\
\text { acidity } \\
(\mathrm{g} / \mathrm{l})\end{array}$ & Variance & Decay \% & Variance \\
\hline 102 & 1,8 & 0,4 & 134 & 46 & 18,7 & 0,9 & 7,1 & 2,0 & 1,7 & 4,1 \\
\hline 108 & 2,1 & 1,0 & 134 & 37 & 18,0 & 0,4 & 7,3 & 1,9 & 0,0 & 0,0 \\
\hline 109 & 2,9 & 0,5 & 170 & 12 & 17,9 & 1,3 & 7,7 & 0,4 & 2,4 & 2,3 \\
\hline 111 & 2,0 & 0,9 & 122 & 29 & 19,1 & 0,9 & 7,9 & 2,1 & 0,5 & 1,2 \\
\hline 114 & 2,5 & 1,3 & 113 & 32 & 17,7 & 1,6 & 7,4 & 2,0 & 2,0 & 4,5 \\
\hline 115 & 3,7 & 0,7 & 130 & 18 & 17,8 & 1,0 & 9,1 & 0,6 & 1,8 & 2,4 \\
\hline 117 & 2,5 & 0,4 & 173 & 40 & 18,2 & 1,3 & 7,2 & 2,2 & 1,6 & 2,3 \\
\hline 122 & 2,8 & 1,0 & 182 & 33 & 18,2 & 1,1 & 7,3 & 1,8 & 0,3 & 0,8 \\
\hline 123 & 3,5 & 1,1 & 150 & 37 & 17,7 & 1,0 & 8,4 & 1,9 & 1,2 & 2,0 \\
\hline 124 & 3,0 & 1,5 & 136 & 22 & 18,0 & 1,1 & 7,7 & 1,7 & 1,0 & 1,5 \\
\hline 125 & 2,7 & 1,7 & 161 & 26 & 18,6 & 1,6 & 7,9 & 1,9 & 1,8 & 3,3 \\
\hline 131 & 2,8 & 1,7 & 148 & 17 & 18,4 & 1,7 & 7,6 & 1,7 & 1,3 & 3,3 \\
\hline 147 & 1,5 & 0,2 & 101 & 12 & 18,8 & 1,0 & 7,8 & 2,4 & 0,0 & 0,0 \\
\hline 165 & 2,7 & 1,5 & 156 & 28 & 18,5 & 1,1 & 7,5 & 2,6 & 2,5 & 5,0 \\
\hline 166 & 1,4 & 0,4 & 150 & 45 & 18,9 & 0,6 & 7,6 & 2,3 & 2,5 & 5,0 \\
\hline Average of 16 clon & 2,5 & 0,9 & 144 & 29 & 18,3 & 1,1 & 7,7 & 1,9 & 1,4 & 2,7 \\
\hline Average of 56 clon & 2,6 & 0,9 & 150 & 31 & 17,7 & 1,3 & 7,6 & 2,0 & 4,6 & 1,6 \\
\hline Difference & $-0,1$ & 0,0 & -3 & -2 & 0,7 & $-0,2$ & 0,1 & $-0,1$ & 3,2 & 1,1 \\
\hline
\end{tabular}

experimental plantations, created in several Hungarian wine regions, after the start of yielding, with 100 to 500 vine-stocks per clone, in a total area of 3 ha.

\section{Results}

\section{First step of the selection}

The old 'Kadarka' stock (planted in 1898) had a significant variability and it was suitable for finding entities appropriate for the selection. Regarding to the 56 elite stocks, a considerable difference could be observed in the morphological characteristic of the yield and even in the performance of the vine-stocks (Figure 1.).

Those vine stocks are said to be valuable, which exceeded the average performance of the stock to a considerable extent, and it can be explained by the genetic background of vine stocks, and their high biological value, instead of a random effect (Figure 1.).

The data of 16 best performing elite stocks were compared with the average values of the 56 elite stocks (Table 2.).
Selection progress can be demonstrated primarily in case of sugar accumulating ability.

The analysis of the 16 most valuable elite stocks was continued in the second step of the selection (second test parcel) in the medium-parcelled experiment (Table 1.).

\section{Second step of the selection}

\section{Results of harvest}

The summarized statistics of the variables (clone, vintage) through measured parameters and through the individual and combined effects demonstrates in the Table 3.

On the basis of the accomplished statistic analysis, including the comparison of each clones and vintages with each other, it is shown that the values of the measured parameters were influenced by the variables collectively and severally, which fact even justifies the diversity of the clones and of the vintages. The significant differences expressing the effects of the variables, in most cases, show a high $(\mathrm{P}=5 \%)$ or rather high $(\mathrm{P}=0,1 \%)$ probability level (Table 3.). 
Table 3. The statistic analysis of individual and combined effects of variables on parameters

\begin{tabular}{|l|c|c|c|c|}
\hline $\begin{array}{c}\text { Treatment/ } \\
\text { Variable }\end{array}$ & Yield & $\begin{array}{c}\text { Averrage } \\
\text { weight of } \\
\text { bunches }\end{array}$ & $\begin{array}{c}\text { Sugar } \\
\text { content }\end{array}$ & $\begin{array}{c}\text { Titratable } \\
\text { acidity of } \\
\text { must }\end{array}$ \\
\hline Clone & $<2 \mathrm{e}-16^{* * * *}$ & $<2 \mathrm{e}-16^{* * * *}$ & $<2 \mathrm{e}-16 * * *$ & $7.42 \mathrm{e}-12 * * *$ \\
\hline Year & $<2 \mathrm{e}-16^{* * *}$ & $<2 \mathrm{e}-16^{* * * *}$ & $3.49 \mathrm{e}-07 * * *$ & $<2 \mathrm{e}-16 * * *$ \\
\hline Clone: Year & $0.01038^{*}$ & $7.55 \mathrm{e}-05^{* * *}$ & $1.01 \mathrm{e}-12 * * *$ & $4.99 \mathrm{e}-16 * * *$ \\
\hline
\end{tabular}

significance level: $* \mathrm{p} \leq 0,05 ; * * * \mathrm{p} \leq 0,001$

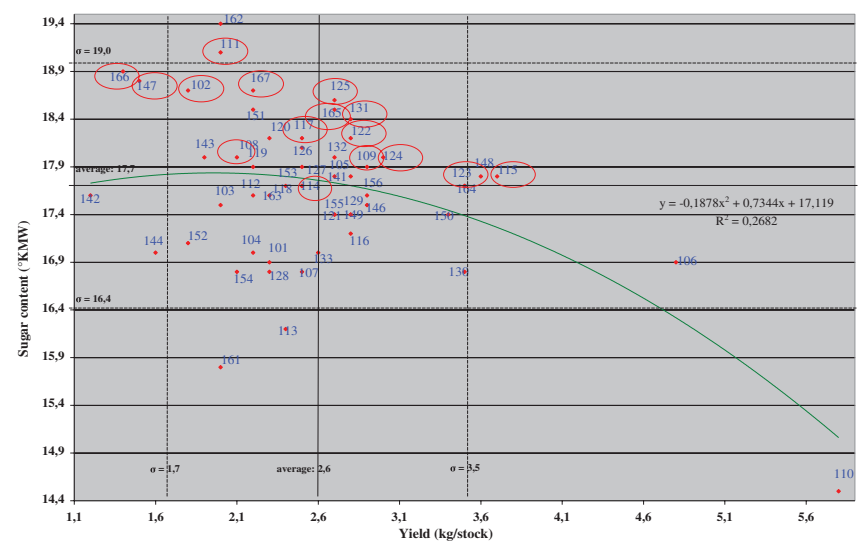

Figure 1. Yield and sugar content of the must of the selected 'Kadarka' elite stocks (Szekszárd - Parászta field, 2001-2009)

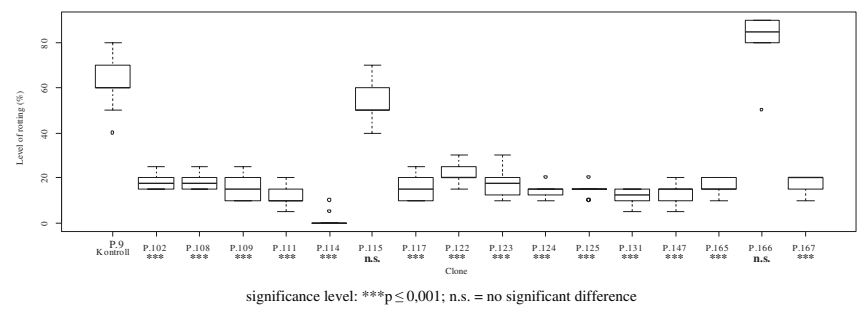

Figure 2. The level of rotting (\%) of clone P. 9 and the selected clones of the grapevine variety 'Kadarka' (Szekszárd - Batti field, 2010)

As the vintage of 2010 was rather rainy, it did not provide opportunity for harvesting of yield in the optimal ripening stage, thus the results of the analysis are demonstrated accordingly the obtained data of 2010 and 2011, instead of the data, gained in the mean of the three examined years (2009-2011) (Figure 2., 3., 4.).

One of the most important aims of the selection was improving the yield security of the grapevine variety 'Kadarka' by reducing its susceptibility to rotting. The level of rotting of the majority of the selected clones did not increase over $25 \%$, even in the vintage of 2010 rather favourable to infection. P. 9 clone could be characterized as possessing one of the highest rotting levels (about $65 \%$ ). The divergence between the selected clones and the control clone, except two clones (P. 115, P. 166), was proved on a high-class $(\mathrm{P}=1 \%)$ significance level (Figure 2.).

The level of rotting is rather influenced by the structure of the cluster. Along with the increase of the quantity of berries, the level of rotting grew to a small degree (Figure 3.). The majority of the selected clones and the P. 9 clone have almost a similar quantity of berries. In spite of this,

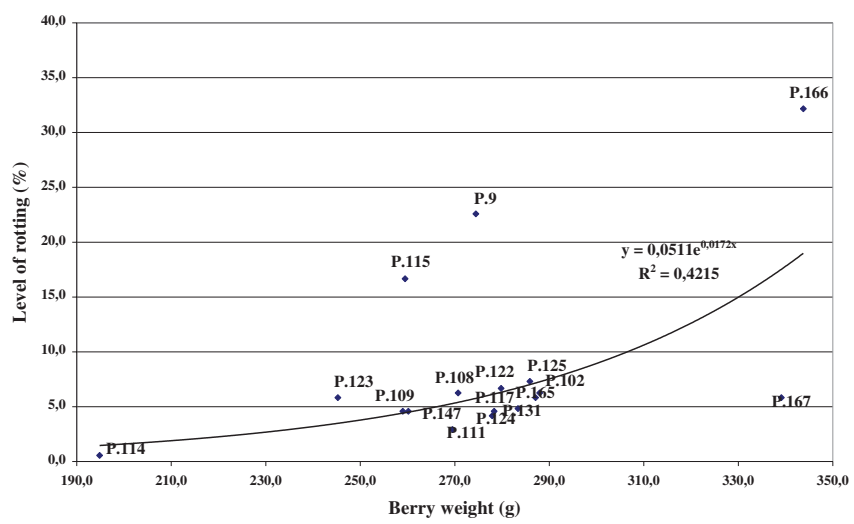

Figure 3. Correlation between the berry weight (100 berries) and level of rotting of clones of 'Kadarka' (Szekszárd - Batti field, 2009-2011)

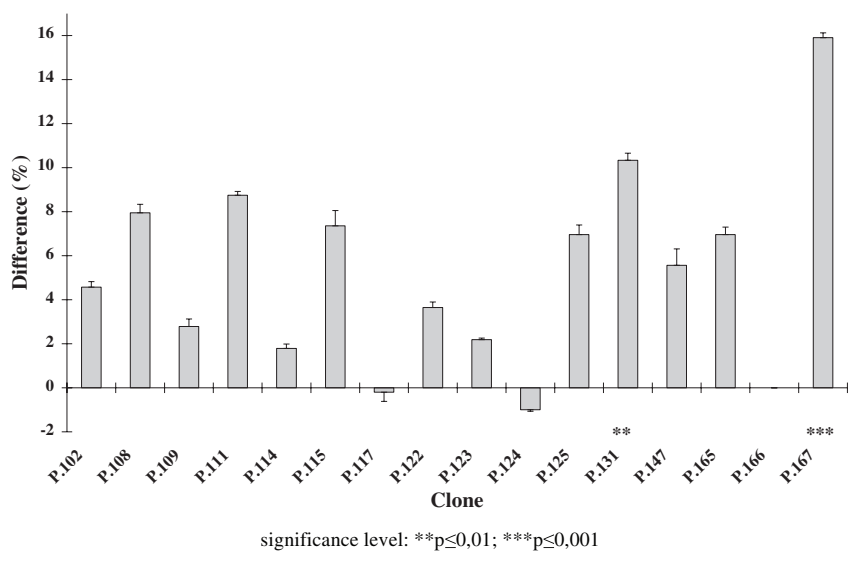

Figure 4. The divergences in sugar content of the must of selected 'Kadarka' clones from the P. 9 clone (Szekszárd - Batti field, 2010)

divergences in the high levels of rotting can be observed, for which the more favourable structure of the cluster and a thicker skin of berries of the selected clones can serve as explanation.

The sugar content of the must of the selected clones of 2010 is compared to the P. 9 control clone, and it is given in percentile divergence (Figure 4.). It can be observed that most of the clones selected ripe with higher sugar content of the must in an unfavourable vintage.

Table 4. contains the harvest data of 2011 and the harvest parameters compared to the P. 9 clone are shown in Figure 5., 6. (The weather conditions of the 2009 and 2011 vintages and the viticultural and enological performance of the clones in these vintages were nearly the same.)

A significant divergence can be shown in comparison to the P. 9 clone, in the quantity of yield, in the average bunch weight and in the sugar content of the must. The P. 114 clone had a lower value and P. 108, P. 117, P. 125 and P. 166 clones had a higher value in the average bunch weight. These results also confirm the observations experienced during the first phase of clonal selection in case of elite stocks (Table 2.) The divergences in the sugar content of the must of the selected clones were statistically lower in case of three selected clones (P. 109, P. 166, P. 167), the remaining clones, similarly to the P. 9 clone, showed a higher value. 
Table 4. Harvest parameters of the clones of 'Kadarka' (Szekszárd, Batti field - 2011)

\begin{tabular}{|l|c|c|c|c|}
\hline $\begin{array}{c}\text { Number of } \\
\text { clon }\end{array}$ & $\begin{array}{c}\text { Yield } \\
\left(\mathrm{kg} / \mathrm{m}^{2}\right)\end{array}$ & $\begin{array}{c}\text { Average } \\
\text { weight of } \\
\text { clusters }(\mathrm{g})\end{array}$ & $\begin{array}{c}\text { Sugar degree } \\
\left({ }^{\circ} \mathrm{KMW}\right)\end{array}$ & $\begin{array}{c}\text { Total acidity } \\
(\mathrm{g} / \mathrm{l})\end{array}$ \\
\hline P.9 & 1,4 & 250 & 20,0 & 5,7 \\
\hline P.102 & $2,2^{*}$ & 309 & 19,1 & 5,5 \\
\hline P.108 & $2,2 *$ & $322^{*}$ & 19,5 & 5,3 \\
\hline P.109 & 2,0 & 281 & $18,7 *$ & 5,4 \\
\hline P.111 & 1,1 & 218 & 20,7 & 5,8 \\
\hline P.114 & 0,8 & $157 * *$ & 19,5 & 5,8 \\
\hline P.115 & 1,7 & 259 & 20,6 & 5,4 \\
\hline P.117 & 2,0 & $317 *$ & 18,9 & 5,9 \\
\hline P.122 & $2,3 *$ & 308 & 18,9 & 5,0 \\
\hline P.123 & 1,7 & 288 & 19,3 & 5,2 \\
\hline P.124 & 1,8 & 247 & 19,0 & 5,3 \\
\hline P.125 & 2,0 & $320 *$ & 18,9 & 5,3 \\
\hline P.131 & 1,7 & 295 & 20,0 & 5,5 \\
\hline P.147 & 1,9 & 261 & 19,4 & 5,1 \\
\hline P.165 & 2,0 & 273 & 19,4 & 5,3 \\
\hline P.166 & $2,3 * *$ & $338 * * *$ & $17,8 * * *$ & 6,1 \\
\hline P.167 & 2,2 & 296 & $18,5 * * *$ & 5,4 \\
\hline
\end{tabular}

significance level from P. $9: * \mathrm{p} \leq 0,05 ; * * \mathrm{p} \leq 0,01 ; * * * \mathrm{p} \leq 0,001$

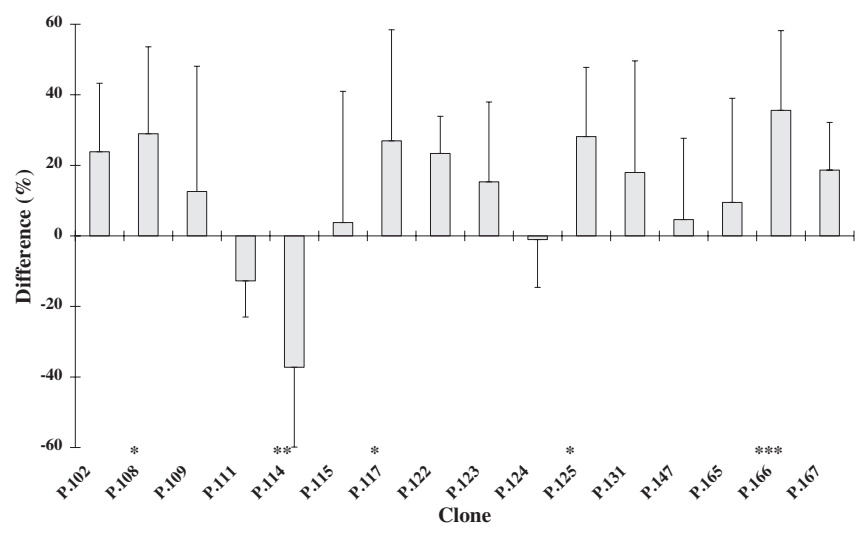

significance level: *p $\leq 0,05 ; * * \mathrm{p} \leq 0,01 ; * * * \mathrm{p} \leq 0,001$

Figure 5. Divergences of 'Kadarka' clones in the average mass of the cluster from the P. 9 clone (Szekszárd - Batti field, 2011)

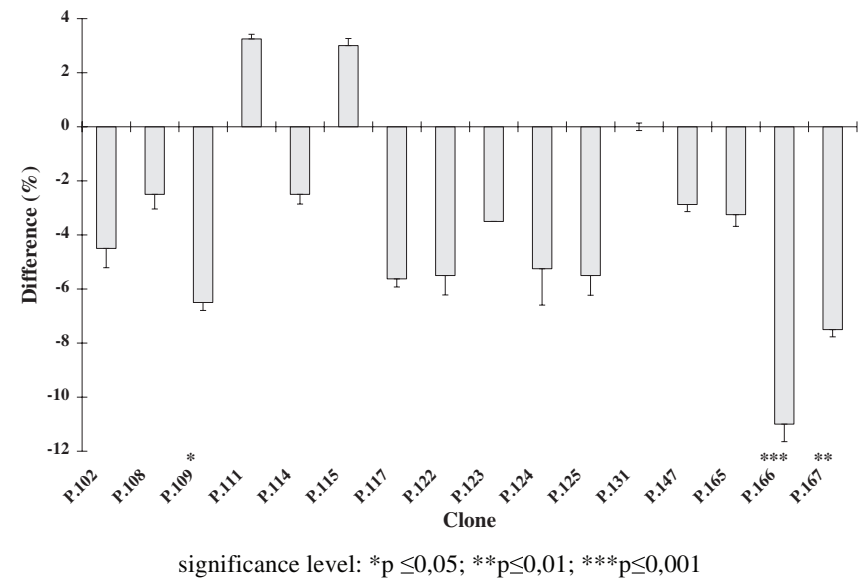

Figure 6. Divergences of the selected 'Kadarka' clones regarding the sugar content of the must from the P. 9 clone (Szekszárd - Batti field, 2011)

\section{Enological results}

The wines of the 2011 vintage were extremely suitable for the evaluation of the particular clones of the grapevine variety 'Kadarka' (Figure 7., 8., 9.). The majority of the selected clones represented a higher colour depth contrarily to the P. 9 clone (Figure 7.).

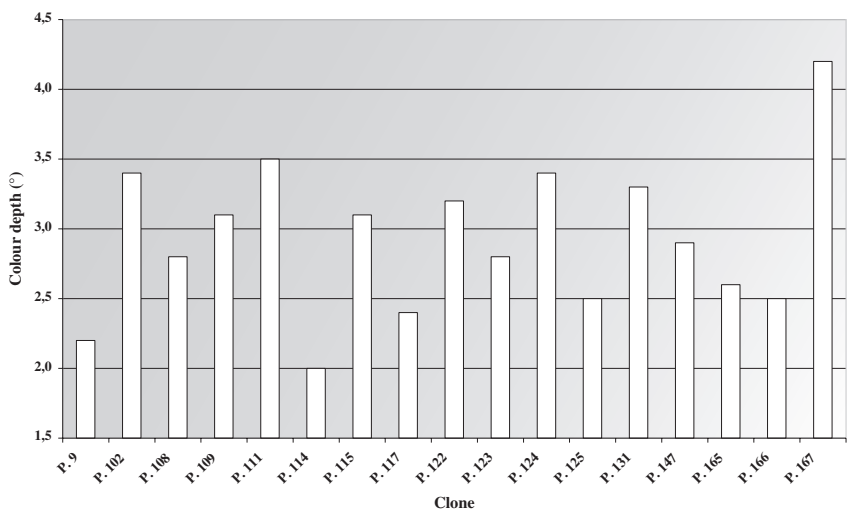

Figure 7. Colour depth of the selected 'Kadarka' clones (Szekszárd, Batti field - vintage of 2011)

The evaluation of the profile analysis made on the wine of the 2011 vintage produced from the selected clones is shown in Figure 8., 9.

P. 124 , P. 147 , P. 167 clones were ranked into the highest level. Considerable divergence among the P. 9 clone and the selected clones could be observed only in case of P. 167 clone. Due to organoleptic examinations, the extraordinary varietal character and harmonic values of the P. 124 clone, the aromatic taste and favourable acid content of the P. 147 clone, and the higher tannin content and deeper colour of the P. 167 clone made these clones outstanding.

In 2010 and in 2012, six clones (P. 111, P. 122, P. 124, P. 131, P. 147, P. 167) - with which the yield security and quality of the grapevine variety 'Kadarka' can be increased - were submitted for state approval according to the analysis of viticultural and enological results (jr. Kozma \& Werner, 2012).

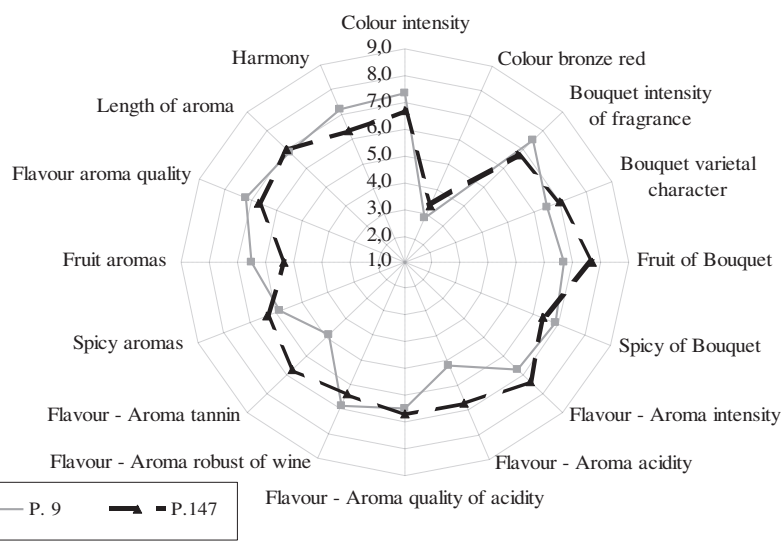

Figure 8. Evaluation of the profile analysis of the wine of the 2011 vintage produced from the P. 147 clone of 'Kadarka' (Szekszárd - Batti field) 


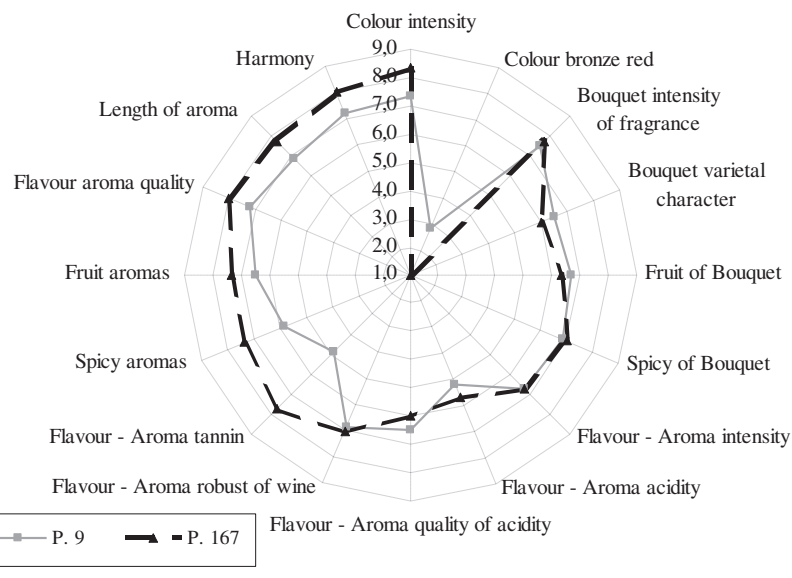

Figure 9. Evaluation of the profile analysis of the wine of the 2011 vintage produced from the P. 167 clone of 'Kadarka' (Szekszárd - Batti field)

\section{Discussion}

Kosinsky (1942) has already described the useful and useless varieties of the grapevine variety 'Kadarka', and highlighted the necessity of variety selection.

Stock, having variability in forms, of the former centuries, mentioned in literary materials, was well represented by the plantation of the grapevine variety 'Kadarka', planted in 1898 (Entz et al., 1869; Ráthay, 1888-1889; Drucker, 1906; Rapaics, 1940; Kozma, 1963; Csávossy, 2002). The old 'Kadarka' stock had a significant variability, and it was suitable for finding entities appropriate for the selection. On the basis of the accomplished statistic analysis, it is shown that the values of the measured parameters were significantly influenced by the clones and vintages collectively and severally on a high significance level and in various extents.

The production value of the grapevine variety 'Kadarka' is considerably decreased by its susceptibility to rotting (Hajdu, 2010). Selected clones, contrarily to the P. 9 clone, could be harvested with rather lower yield loss and with higher sugar content of the must in the year of 2011, favourable to grey rot infection. P. 122, P. 124, P. 147 and P. 167 clones reached outstanding quality during the organoleptic examinations. In most cases, the colour depth of the selected clones exceeded the value of P. 9 clone. In the experiment (in 2011) the value of colour depth of the P. 9 clone was under the values described by Németh (1958).

The collective cultivation of the new selected clones promotes not only the numeral and proportional selection appropriate to the ecological conditions of the cultivation area but the creation of various wine styles by blending their wines.

\section{Conclusion}

Jr. Kozma et al. (2010) emphasizes that the preservation and improvement of the biological basis mean a strategic task in vine production. The research, serving this purpose, confirms the statements mentioned in the literary materials, according to which the quality and yield security of the grapevine variety 'Kadarka' can be improved by clonal selection (Kozma, 1954, 1957, 1958/a, b, 1963; Németh, 1958, 1966, 1967/a, b; Hajdu, 2006, 2010, 2012; Werner et. al, 2009; jr. Kozma et al., 2010).

The new six clones submitted for state approval help to ensure the competitiveness of 'Kadarka', previously representing a significant role in Hungary, in compliance with the new market and environmental challenges that is confirmed by the results of commercial plantations.

\section{Acknowledgements}

The research work of the Institute of Viticulture and Enology Pécs was supported by the NKFP 4/036 project of the Széchenyi Plans titled „Kárpát-medence kertészeti növényei genetikai diverzitásának feltárása, megörzése és hasznositása a lakosság életminöségének javitására”, and the NKFP4-00017/2005 project of Jedlik Ányos titled „A magyar borok versenyképességének megalapozása hagyományos és biotechnológiai módszerekkel, az eredetvédelem és a marketing fejlesztésével". We would like to thank the work of the technical staff of the Institute of Viticulture and Enology Pécs, who provided an essential assistance in the recording, systematisation of the data and in the production of wine samples. We are grateful to the owners (Hladics Károly - Szekszárd, Parászta filed; Heimann Családi Birtok - Szekszárd, Batti field) for the professional nursing of the plantations and for ensuring the optimal conditions of the working areas.

\section{References}

Andrásfalvy, B. (1999): A Kadarka-kultúra Magyarországon. In: Benyák, Z. (szerk.) (1999): Borok és korok, bepillantás a bor kultúrtörténetébe. Hermész Kör. Budapest. 133-144.

Bessis, R. (2007): Evolution of the grapevine (Vitis vinifera L.) imprinted by natural and human factors. Canadian Journal of Botany. 85 (8): 679-690.

Boursiquot, J-M. \& This, P. (1999): Essai de définition du cépage. Le Progrés Agricole et Viticole. 116 (17): 359-361.

Cindric, P., Korac, N. \& Kovac, V. (2000): Sorte vinove loze. Metode i rezultati ispitivanja. Novi Sad.

Csávossy, Gy. (2002): Jó boroknak szép hazája, Erdély. Mezögazda Kiadó. Budapest.

Csepregi, P. (1982): A szőlő metszése és fitotechnikai müveletei. Mezögazdasági Kiadó. Budapest.

Csepregi, P. (1997): Szőlőtermesztési ismeretek. Mezögazda Kiadó. Budapest.

Dejeu, L. (2012): Wine grapes. In: Robinson, J., Harding, J. \& Vouillamoz, J. (2012): Wine grapes. New York.

Drucker, J. (1906): A Nemes Kadarka. Borászati Lapok. Pátria Irod. Váll. és Nyomdai Rt. Budapest.

Entz, F., Málnay, I. \& Tóth, I. (1869): Magyarország borászata. Pest.

Eperjesi, I., Kállay, M. \& Magyar, I. (1998): Borászat. Mezőgazda Kiadó. Budapest. 
Hajdu, E. (2006): A szőlő szelekciós nemesítése és a magyarországi eredmények. Kertgazdaság. 38.(4): 39-45.

Hajdu, E. (2010): A Kadarka-nemesítés eredményei. Kertgazdaság. 42 (1): 27-37.

Hajdu, E. (2012): A tudomány megírta. In: Buza, P. \& Sebestyén, L. (szerk.) (2012): A nagy Kadarka könyv. Szaktudás Kiadó Ház. Zrt. 37-52.

Halász, G. (2010): Szőlő- és almafajták jellemzése mikroszatellit markerekkel. Doktori értekezés. Szent István Egyetem. Gödöllö.

HNT (Hegyközségek Nemzeti Tanácsa) (2011, 2012): Szőlöültetvények területi adatai borvidékenként, Budapest.

Kosinsky, V. (1942): Szőlőfajtaismeret. Borászati Lapok. Budapest.

Kozma, P. (1954): A Kadarka szőlőfajta virágtípusai, a virágtípusok változékonysága és termékenysége. Kertészeti és Szölészeti Föiskola Évkönyve. Budapest.

Kozma, P. (1957): Így szelektáljuk a Kadarkát! Mezőgazdasági Kiadó. Budapest.

Kozma, P. (1958/a): A Kadarka szőlőfajta különböző ivari változatainak összehasonlító szervetlen kémiai jellemzése. Szölészeti Kutató Intézet Évkönyve. Budapest. 11 (1): 227-240.

Kozma, P. (1958/b): A szőlő fajtafenntartó nemesítés módszerei és eddigi eredményei Magyarországon. Nemzetközi Mezőgazdasági Szemle 2. Budapest.

Kozma, P. (1963): A szőlő termékenységének és szelektálásának virágbiológiai alapjai. Akadémiai Kiadó. Budapest.

Kozma, P. jr., Werner, J., Csikászné, K. A. \& Hoffmann, S. (2010): Németh Márton hagyatéka Pécsett, kutatásainak hatása a mai szőlőkultúrára. Kertgazdaság. 42. (3-4.): 56-72.

Kozma, P. jr. \& Werner, J. (2012): Újabb változatokkal számolhatunk. In: Buza, P. \& Sebestyén, L. (szerk.) (2012): A nagy Kadarka könyv. Szaktudás Kiadó Ház. Zrt. 52-56.

Luntz, O. (1990): A klónszelekció hazai helyzete és eredményei. Szölötermesztés és Borászat. Kecskemét. 12 (1-2): 2-7.

Nedelcsev, H. (1938): Ampelografija C. Pridvorna pecatnitca. 223. In: Kondarev, M., Kirtev, P., Csankov, v., Zankov, Z., Csakov, D \& Getov, G. (szerk.) (2010): Bulgarszka Ampelografija. Csasztna Ampelografija. Sofia. Tom 2. 167-180.

Negrul', A. M. (1946): Proiszhozsdenie kulturnogo vinograda i ego klaszifikacija. Ampelografija SzSzSzR. Moszkva I. 1959-216.

Németh, M. (1958): A borszőlőfajták összehasonlító értékvizsgálata és klónszelektálása. Szölészeti Kutató Intézet Évkönyve. 11 (1): 261-326.
Németh, M. (1966): Borszőlőfajták. In: Hegedűs, Á., Kozma, P. \& Németh M. (1966): A szőlő (Vitis vinifera L.). Magyarország kultúrflórája. Akadémiai Kiadó. Budapest.

Németh, M. (1967/a): Ampelográfiai album - termesztett borszőlőfajták 1. Mezögazdasági Kiadó. Budapest.

Németh, M. (1967/b): A klónszelekciós szőlőnemesítés módszere Pécsett és az elért eredmények. Szölö és gyümölcstermesztés III. Budapest. 41-86.

Németh, M. (1970): A szőlőfajták hozamnövelése és minőségjavítása klónszelektálással. Agrártudomány Közlemények. 29 (3): 159-190.

OIV. (Iternational Organisation of the Vine and Wine), (2009): OIV descriptor list for grape varieties and Vitis species $\left(2^{\text {nd }}\right.$ edition). Organisation Internationale de la Vigne et du Vin, 18 rue d'Aguesseau, 75008 Paris, France.

Rapaics, R. (1940): A magyar gyümölcs. Királyi Magyar Természettudományi Társulat. Budapest.

Rácz, J. (1997): Kétszáz magyar szőlőnév. Magyar Nyelvtudományi Társaság. Budapest.

Ráthay, E. (1888-1889): Die Geschlechtverhältnisse der Reben und ihre Bedeutung für den Weinbau. I-II. Pest.

R Development Core Team, (2011): R: A language and environment for statistical computing. R Foundation for Statistical Computing, Vienna, Austria. ISBN 3-900051-07-0. URL http:// www.R-project.org/

Robinson, J., Harding, J. \& Vouillamoz, J. (2012): Wine grapes. New York.

Rohály, G. (2012): Wine grapes. In: Robinson, J., Harding, J. \& Vouillamoz, J. (2012): Wine grapes. New York.

Schmid, J., Manty, F. \& Lindner, B. (2009): Geisenheimer Rebsorten und Klone. Geisenheimer Berichte 67. Forschunganstalt Geisenheim.

Wegscheider, E., Benjak, A. \& Forneck, A. (2009): Clonal variation in Pinot noir revealed by S-SAP involving universal retrotransposon-based sequences. American Journal of Enology and Viticulture. 60 (1): 104-109.

Werner, J., jr. Heimann, Z. \& Kozma, P. (2009): A Kadarka szőlőfajta minőségének növelése újabb klónok kiválasztásával. $X V$. Növénynemesitési tudományos napok. Külön kiadvány: Hagyomány és haladás a növénynemesitésben. 542-546. 